\title{
FEATURES OF PUBLIC-GEOGRAPHICAL MAPPING OF CONFESSIONAL SPACE OF UKRAINE
}

\author{
Ivan Kostaschuk \\ Department of Geography of Ukraine and Regional Studies, \\ Chernivtsi National University named after Yuriy Fed'kovych \\ 2 Mykhaylo Kotsyubynskiy str., Chernivtsi, Ukraine, 58000 \\ ivan_kostaschuk@ukr.net
}

\begin{abstract}
A universal author's methodology for mapping the confessional space of the territory with the use of special methods and means is proposed. In the process of scientific research, the following tasks are accomplished:

1) an analysis of existing cartographic materials is carried out, where the confessional structure and other scientific sources are displayed;

2) the main advantages and disadvantages of using certain methods, means, techniques and symbols are highlighted;

3) its own methodology for mapping the confessional space of individual territories is developed (on the example of the territory of Ukraine and its individual regions).

The offered results of scientific researches are approved at scientific conferences and congresses and have received positive responses of leading scientists of Ukraine in the field of cartography. As a result of such studies and practical application of the mapping methodology, we created a series of maps (more than 120) reflecting the confessional space of Ukraine at the level of administrative and territorial regions and cities of regional importance. We also built a map for Volyn, Rivne, Lviv, Ternopil, Khmelnytsky, Chernivtsi, Ivano-Frankivsk and Zakarpattia regions at the settlement level. This allows to identify the various areas of possible interconfessional confrontations, as well as promising destinations for the development of religious tourism.

The main scientific result of the scientific research is the proposed methodology for mapping the confessional space, as well as creating tourist maps for the development of religious tourism. These results create the foundation for further scientific reflection on the process of mapping and cartographic monitoring of confessional space. They can serve as basic information for regulating interfaith relations at various levels, which is relevant for Ukraine today.
\end{abstract}

Keywords: temporal rule, temporal knowledge base, information control system, event log, event attributes.

\section{Introduction}

Mapping as a way of conveying information about natural or social phenomena and processes of the territory today is one of the main methods of reproducing spatial irregularities and polarizations. More and more often, cartographic images are used to reproduce the territorial organization of any phenomena and processes and report them to an ordinary person. That's why there is a problem to choose such methods and means of mapping correctly and most importantly enough will be able to convey information to its ordinary reader.

Particularly relevant for Ukraine is the issue of the development of religious tourism as a promising area among all types of tourism. Therefore, the creation of tourist maps is one of the important tasks of Ukrainian scientists in the field of geography, cartography and tourism.

The relevance of this research topic is also confirmed by the tense interconfessional situation on the territory of Ukraine that developed between the Ukrainian Orthodox Church and the Ukrainian Orthodox Church of the Kyiv Patriarchate in 2014. Cartographic monitoring of the confessional space is the most important source of information about its territorial abolition, which is able to identify areas of distribution of various faiths and prevent religious conflicts. Also, with the help of the map of religious and tourist potential, it is possible to clearly identify promising destinations for the development of religious tourism and, accordingly, better plan tourist trips.

\section{Materials and methods of research}

The main source and information materials for the study are:

1) available cartographic materials from the end of the 19th century, where the confessional structure of the population is reflected; 
2) scientific literary sources dedicated to issues of general and thematic (namely socio-economic) mapping;

3) statistical data of the confessional structure of the regions of Ukraine.

In the process of conducting scientific research, we used both general scientific and specific methods of scientific research. The most important method of scientific research is certainly the cartographic method, which has two aspects of use, namely:

1) analysis of the existing maps is carried out where the confessional space is reproduced in order to identify the advantages and disadvantages of the used methods and means of mapping;

2) their own cartographic models are created with the display of confessional space and their advantages and disadvantages are analyzed.

In addition to the cartographic method of scientific research, methods of analysis and synthesis, the use of literary sources, comparative-geographical, mathematical, statistical, and others are used. The combination of the use of these methods of scientific research allowed us to obtain appropriate scientific conclusions and propose new approaches for mapping the confessional (religious) space of Ukraine and its individual regions.

\section{Results of scientific research on the methodology of mapping of confessional space}

The religious space of Ukraine is a complex, multi-religious socio-cultural formation, manifests itself and affects many processes [1-10]. Its mapping today raises many questions and creates many problems due to the lack of statistical information on the number of supporters of a particular confession. These data can only be obtained from population censuses, but there is no graph on religious affiliation in the census questionnaire. Today, the basic statistical information reproducing religious space data on the number of registered (unregistered, but operating) religious organizations and communities. Indicators of providing confessions with cult constructions and clergymen, printed periodicals, educational institutions of different levels, etc. are also quite important [5].

To develop a methodology for mapping the confessional space of Ukraine and its individual parts, the following algorithm for scientific research has been developed, where its main stages are envisaged: preparatory, analytical and basic.

During the preparatory stage, an information base for scientific research was formed, namely: statistical materials describing the confessional space of the regions of Ukraine, cartographic materials from the late 19th century, and also literary sources of scientists in the field of geography of religion were collected [1-32].

The maps are particularly interesting, they are highlighted in the Internet and cover the distribution of the confessions (Fig. 1) in some countries or territories that are superior in administrative-territorial units (in the USA, Turkey, Romania, Germany and others).

During the analytical stage it is necessary to classify the collected information sources on the following grounds:

1) by confessional membership (Ukrainian Orthodox Church, Ukrainian Orthodox Church of Kyiv Patriarchate, Ukrainian Greek Catholic Church, etc.) [26]. The groupings of communities of different confessions on Orthodox, Catholic, Protestant, Muslim and other subspaces and with close interfaith groups have been developed, which is reflected in Table 1. Such group is explained by the fact that all denominations will be impossible to map;

2) by the state of worship (acting, partially acting, not acting);

3) by the preservation degree (destroyed, dilapidated, restored and newly built);

4) by the architectural style (Ukrainian Baroque, Gothic, Cossack, wooden home, etc.); ica, etc.);

5) by religious significance (monastery, cathedral, parish church, synagogue, church, basil-

6) by the creation time (medieval, Cossack period, 18-19 centuries, beginning and middle of the 20th century, the end of the 20th - the beginning of the 21st century).

Also during the analytical stage of creating cartographic models of confessional space, analysis of literature sources and existing cartographic works is conducted and methods and means of mapping are selected [25]. 


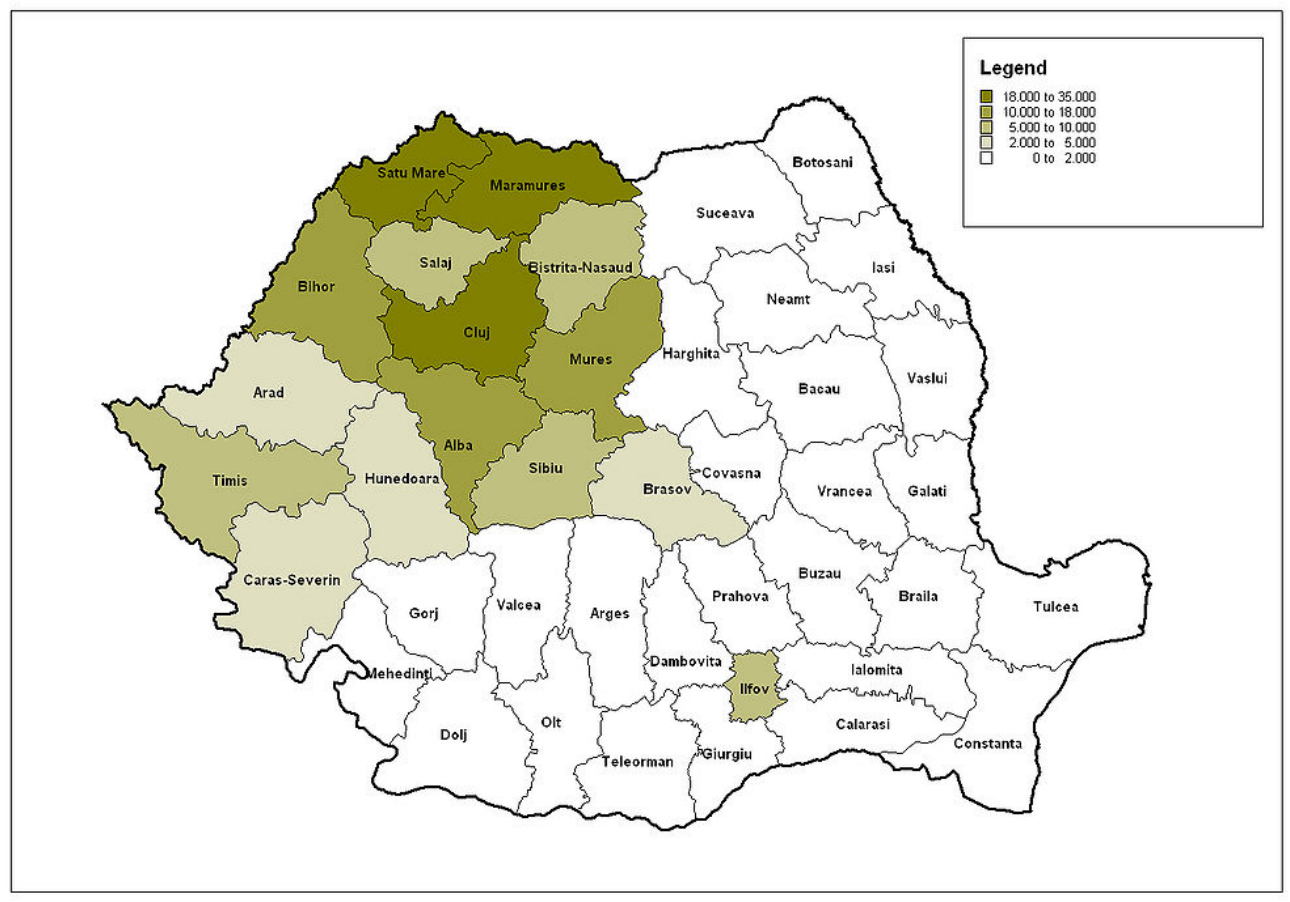

$a$

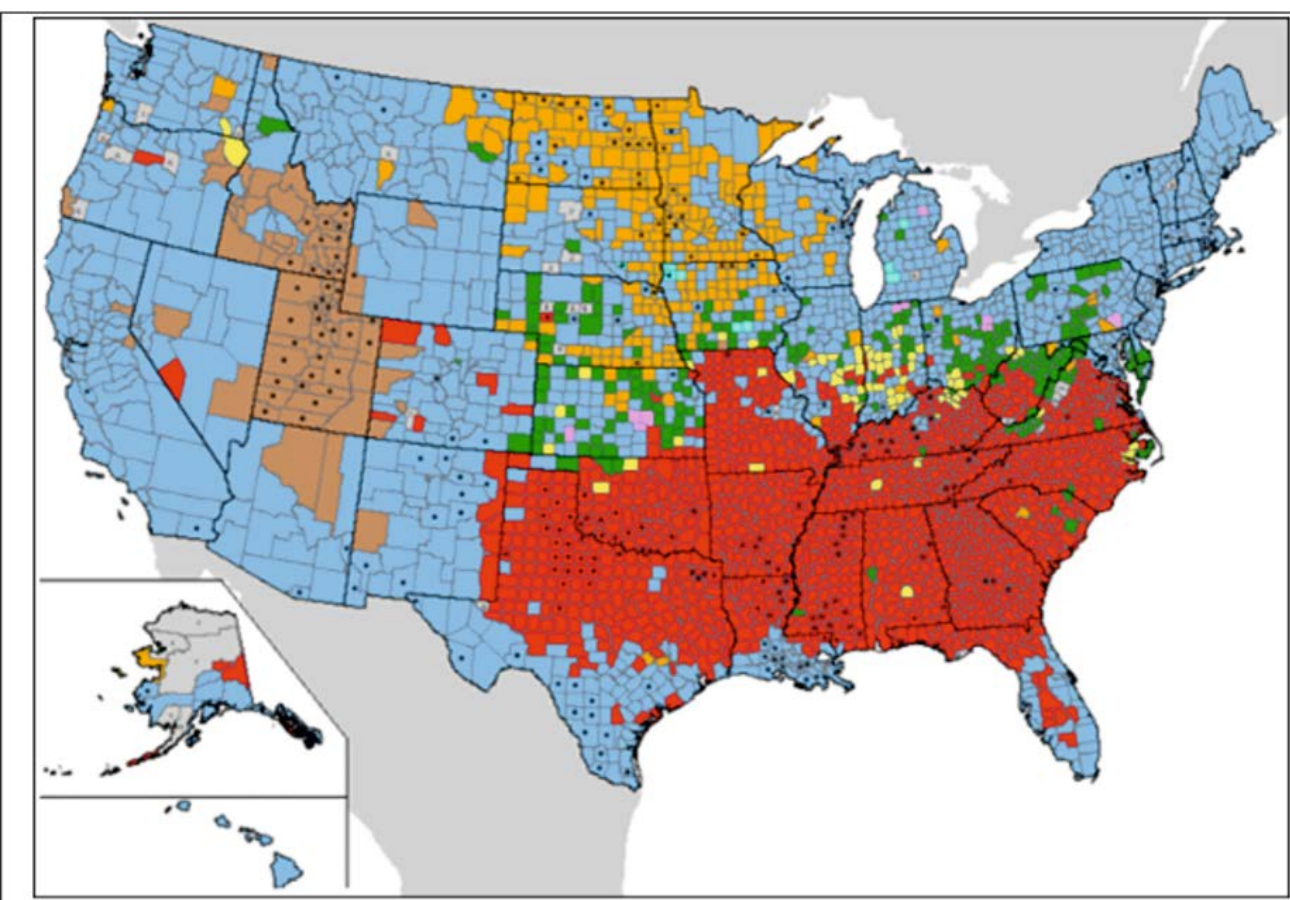

1. Baptists, 1302 districts

2. Catholics, 1164 counties

3. Lutherans, 250 districts

4. Methodists, 219 counties

5. Church of Jesus Christ of Latter-day

Saints (Mormons), 80 districts

6. Church of Christ, 12 districts

7. Other, 35 districts

8. Reforms, 9 districts

9. - Areas in which the overwhelming majority of parishioners of this denomination

$b$

Fig. 1. Distribution of Greek Catholics in Romania:

$a$-according to the 2002 census; $b$ - the dominant communities of the confession in the US 
The most important is the main stage of scientific research when the methodology was developed and mapping of the territory of Ukraine and its individual regions was carried out in accordance with the needs of Ukraine [24].

When mapping the religious space of the regions of Ukraine at the highest administrative-territorial level, it is expedient to use such methods of mapping as a circular or square diagram [1]. Both of them (Fig. 2) will reflect the religious distribution of communities according to their specific gravity, and their size is the total number of communities in cities of state significance (Kyiv, Sevastopol), the region or Crimea. It is advisable to reflect the level of localization of communities in the territory that can be reproduced as the ratio of the number of religious communities to the area (the localization index proposed by A. Kovalchuk [14]), the population size or the number of settlements. Thus, mapping was used in drawing up a map of "Religious Organizations" in the National Atlas of Ukraine [18].

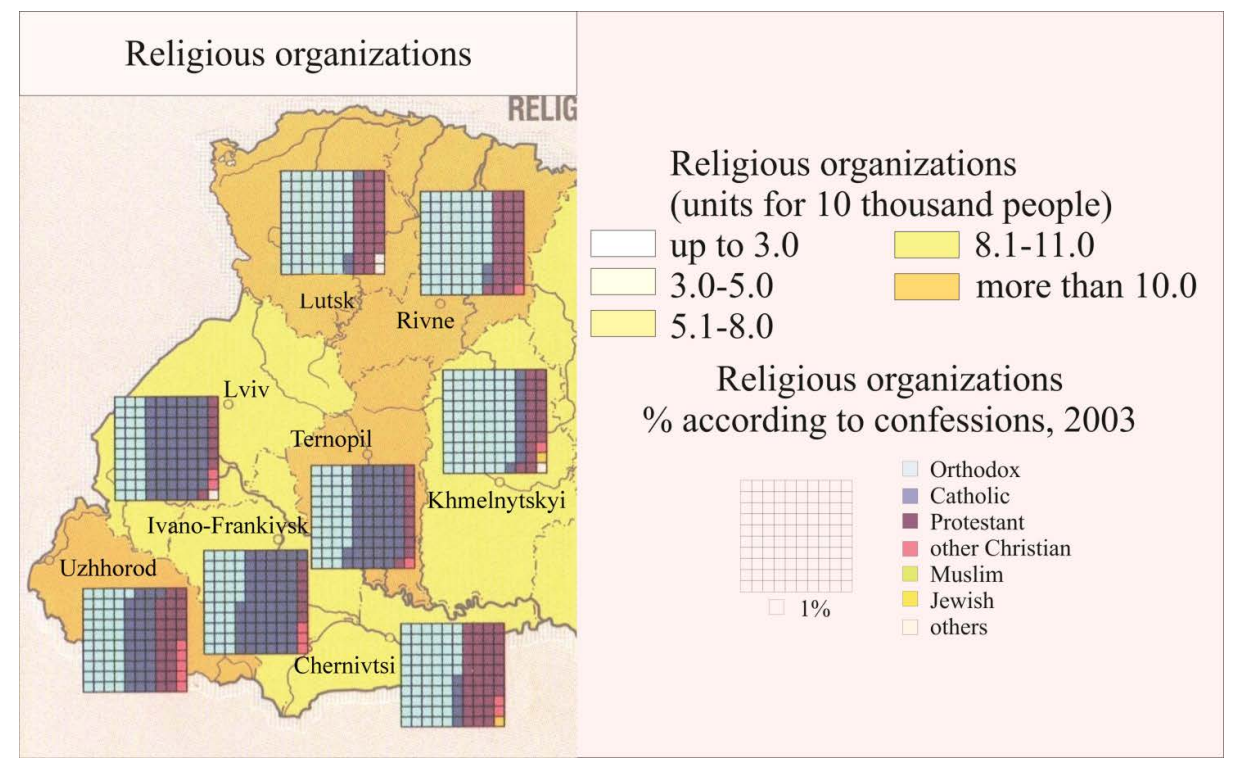

$a$

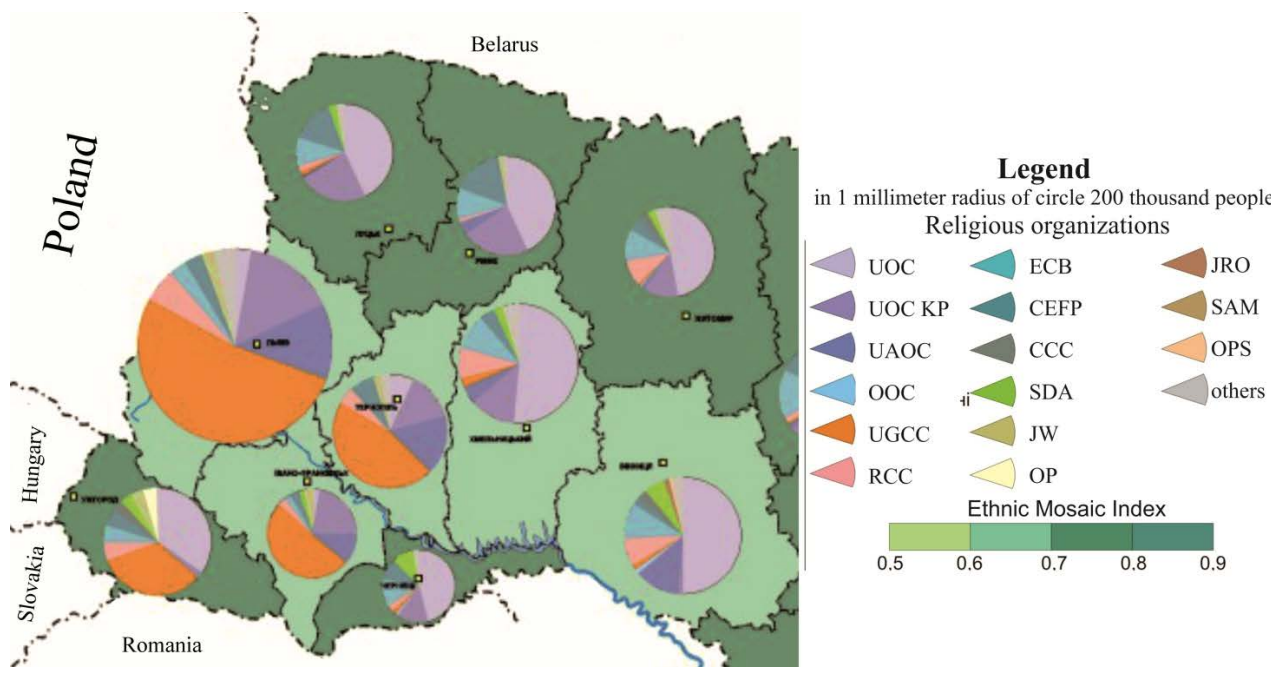

$b$

Fig. 2. Fragment and legend of the map: $a-$ "Religious Organizations" from the National Atlas of Ukraine; $b$ - "The Confessional Space of Ukraine"

Several other approaches for mapping should be done when concluding maps of the religious space of certain regions of Ukraine. When creating a map scheme, for example, in the Ternopil re- 
gion, at the level of administrative regions, it is possible to use the same approaches as for the map of Ukraine [11]. But if conducting a detailed study of religious space at the level of settlements, then it is necessary to change the approaches to choosing methods and means of mapping. In particular, it is proposed to use the method of a circular chart in which to accurately reflect the number of communities even if they are all of the same denomination to display the confessional space of a particular settlement. The size of the circle, in our opinion, should reflect the total number of religious communities. The background on such maps can also display the localization of communities both in terms of area and population. If the size of the pie chart shows the number of communities, and not the size of the settlement, then it is necessary to display the binding of the religious population space to the background (Fig. 3).

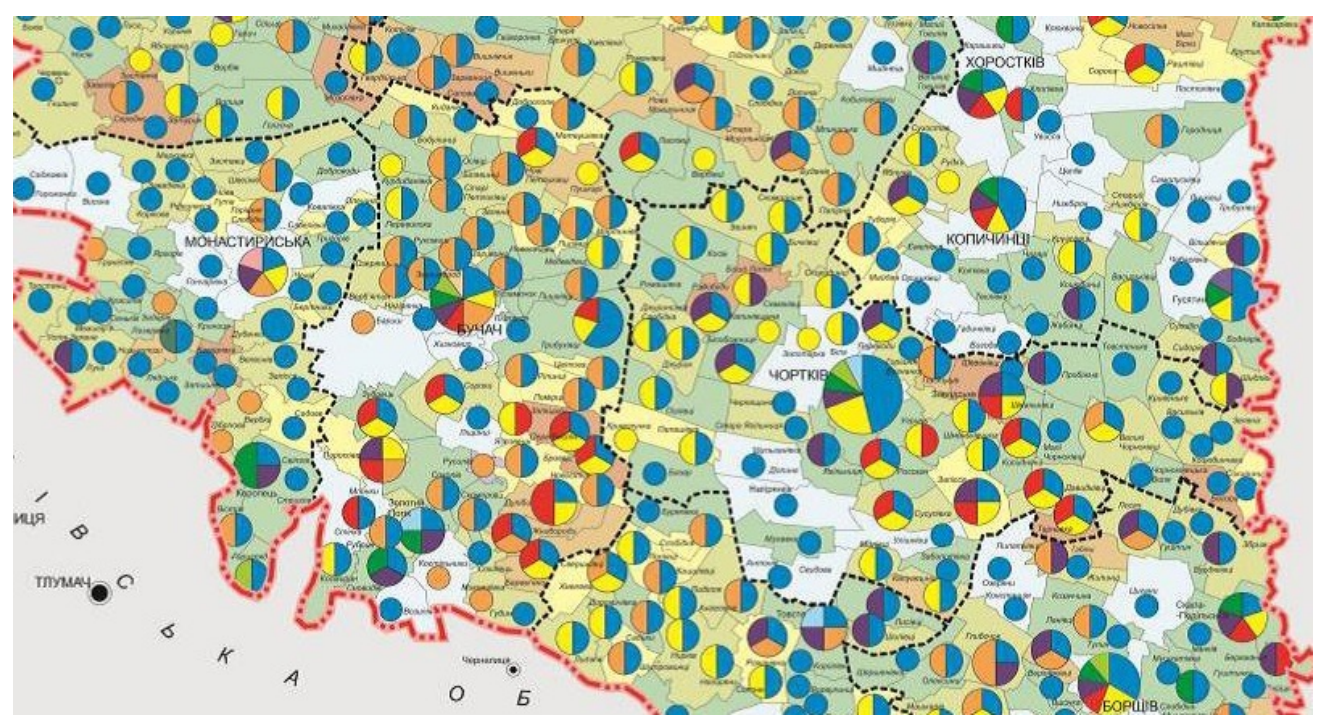

\section{Legend}

Religious organizations
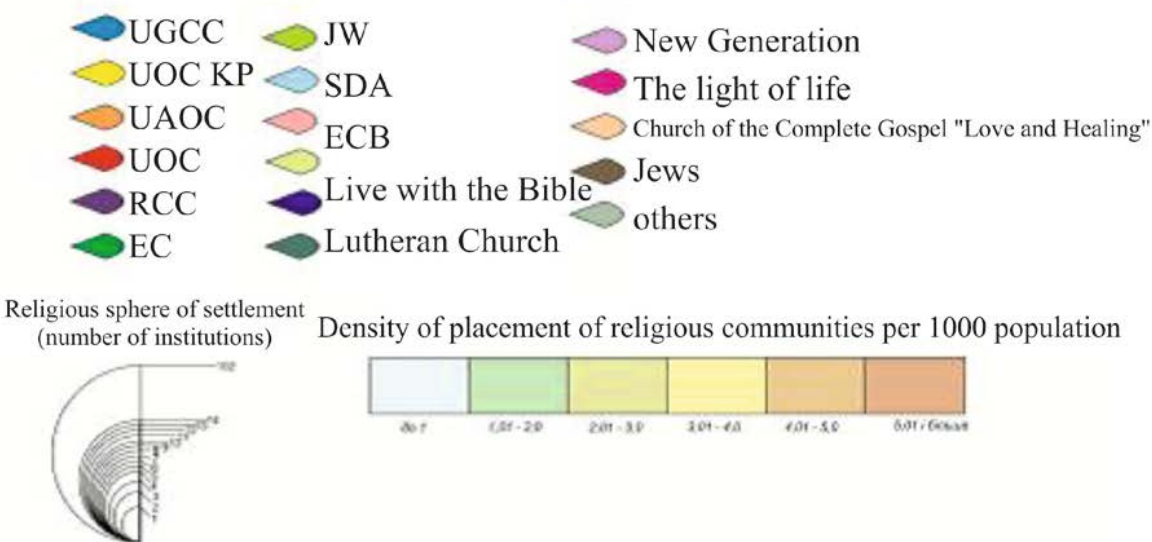

Fig. 3. Fragment and legend of the map scheme "Confessional structure of the Ternopil region" carried out at the level of settlements [11]

Such approach will help to better understand the level of confessional dispersion, depending on the size of the settlement after the population. It is established that usually a larger settlement has more faiths and, accordingly, communities. However, in the poly-confessional regions it is possible to observe the situation when in a settlement with a population of 500 people there are registered 2-3 communities of different confessions, which is explained by various factors. Therefore, such map scheme will help to predict the perception of religious space, depending on the size and socio-economic and humanitarian development of settlements, especially rural ones. 
Another problem that is uncertain until the end is the use of a color scheme for mapping communities of different denominations (Table 1). Let's believe that here it is worth using as much as possible the colors of the most faiths in their mapping. For example, for the UOC it is necessary to use red color, UOC-KP - dark-headed, UGCC - orange, pink and purple shades used for Protestant communities of different directions, light green for Muslims, gray for Jews and the like.

Table 1

Recommendations on the use of color scheme in the mapping of confessional space in the region

\begin{tabular}{|c|c|c|c|}
\hline The name of the confession & $\begin{array}{c}\text { Abbrevi- } \\
\text { ation }\end{array}$ & Color & Explanation of the selected color \\
\hline \multicolumn{4}{|c|}{ ORTHODOX SUBSPACE } \\
\hline 1 & 2 & 3 & 4 \\
\hline Ukrainian Orthodox Church & UOC & & $\begin{array}{l}\text { It symbolizes the blood of Jesus Christ, the color of the mantle of } \\
\text { the Most Holy Ecumenical Patriarch, Archbishop of Constantino- } \\
\text { ple - New Rome }\end{array}$ \\
\hline $\begin{array}{l}\text { Ukrainian Orthodox Church of Kyiv } \\
\text { Patriarchate }\end{array}$ & UOC KP & & $\begin{array}{l}\text { It symbolizes the idea of self-sacrifice, something new, as well as } \\
\text { sky and height. The color of the mantle of the patriarch of Kiev } \\
\text { and all Rus-Ukraine }\end{array}$ \\
\hline $\begin{array}{l}\text { Ukrainian Autocephalous Orthodox } \\
\text { Church and Ukrainian Autocephalous } \\
\text { Orthodox Church (updated) }\end{array}$ & UAOC & & $\begin{array}{l}\text { It symbolizes the idea of self-sacrifice, something new, as well as } \\
\text { sky and height. The color of the mantle of the Metropolitan of Kiev } \\
\text { and All Ukraine, the Primate of the UAOC }\end{array}$ \\
\hline $\begin{array}{l}\text { Russian Orthodox Old Believer Church } \\
\text { (Belokrinitskoe, Novozybkovskoe and } \\
\text { Bespopovskoe consent) }\end{array}$ & ROOBC & & $\begin{array}{l}\text { It symbolizes life. The color of the mantle of the patriarch of the } \\
\text { Russian Orthodox Old Believer Church }\end{array}$ \\
\hline $\begin{array}{l}\text { The Russian Orthodox Church Outside } \\
\text { of Russia and the Russian True Ortho- } \\
\text { dox Church }\end{array}$ & $\mathrm{ROCO}$ & & $\begin{array}{l}\text { It symbolizes life and the beginning of restoration (spring). Af- } \\
\text { ter reunification with the Russian Orthodox Church, the ROCAO } \\
\text { began its new era of development. Green is also the color of the } \\
\text { patriarch of Moscow and All Russia }\end{array}$ \\
\hline $\begin{array}{l}\text { Other Orthodox denominations and } \\
\text { trends }\end{array}$ & OOC & & $\begin{array}{l}\text { Assigned from free colors of colors as they approach the dominant } \\
\text { confession }\end{array}$ \\
\hline
\end{tabular}

\section{CATHOLIC SUBSPACE}

Ukrainian Greek Catholic Church

Mukacheve Greek-Catholic Diocese

The Roman Catholic Church

Other Catholic confessions and trends (Armenian-Catholic Church in Ukraine)

\section{UGCC}

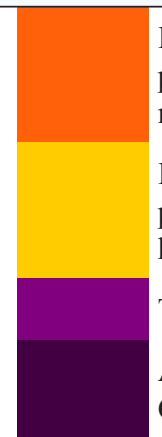

It symbolizes the combination of Orthodox and Catholic principles. The color of ribbons on the black robe of the Patriarch-Primate of the UGCC

It symbolizes the combination of Orthodox and Catholic principles. The color of the general background on the emblem of $\mathrm{Mu}-$ kachevo Bishop

The color of the stone amethyst - symbolizes the cardinal dignity.

Assigned from free colors of colors as they approach the Roman

Catholic Church as the Confessions of the Holy See

\section{EASTERN EARLY-CHRISTMAS SUBSPACE (CHURCHES OF THE EAST)}

Armenian Apostolic Church and Apostolic Holidays - Assyrian Church of the East
Symbolizes apostolic ministry. The color of the mantle of the Catholicos Patriarch of the Church of the East

\begin{tabular}{lll}
\hline \multicolumn{2}{c}{ PROTESTANT SUBSPACE } \\
\hline $\begin{array}{l}\text { All-Ukrainian Union of Evangelical } \\
\begin{array}{l}\text { Christian Baptists } \\
\text { ECB }\end{array}\end{array}$ & $\begin{array}{l}\text { Color from the world emblem of Baptists (not from the All- } \\
\text { Ukrainian Union of Evangelical Christian Baptist Churches) }\end{array}$
\end{tabular}


Continuation of Table 1

\begin{tabular}{|c|c|c|c|}
\hline 1 & 2 & 3 & 4 \\
\hline Other Baptist Religious Organizations & OECB & & $\begin{array}{l}\text { It is assigned from free colors of color scale as it approaches the } \\
\text { main denomination - ECB }\end{array}$ \\
\hline Evangelical Christians & EC & & $\begin{array}{l}\text { The color is appropriated on the approach to the Baptists, and in } \\
\text { the doctrine and religious outlook these confessions are very close }\end{array}$ \\
\hline $\begin{array}{l}\text { All-Ukrainian Union of Christians of } \\
\text { the Evangelical Faith (Pentecostals) }\end{array}$ & CEFP & & $\begin{array}{l}\text { The color of the Holy Spirit descended on the apostles on the fif- } \\
\text { tieth day after the Resurrection of Christ. It is this day is the main } \\
\text { one in the CEFP }\end{array}$ \\
\hline $\begin{array}{l}\text { Other religious organizations of Chris- } \\
\text { tians of the Evangelical Faith }\end{array}$ & OEFP & & $\begin{array}{l}\text { Assigned from free colors of colors as they approach the main de- } \\
\text { nomination - OEFP }\end{array}$ \\
\hline $\begin{array}{l}\text { Ukrainian Union Conference of the } \\
\text { Seventh-day Adventist Church and other } \\
\text { religious organizations of Seventh-day } \\
\text { Adventists }\end{array}$ & SDA & & Color from the official emblem of this religious denomination \\
\hline $\begin{array}{l}\text { German Evangelical-Lutheran Church; } \\
\text { Ukrainian Lutheran Church and other } \\
\text { Lutheran churches }\end{array}$ & ULC & & $\begin{array}{l}\text { Color from the general background of the official emblem of the } \\
\text { Lutheran. Together with the red color is used in many Lutheran } \\
\text { heraldic works }\end{array}$ \\
\hline $\begin{array}{l}\text { Zakarpattia Reformed Church and other } \\
\text { Reformed churches }\end{array}$ & $\mathrm{ZRC}$ & & $\begin{array}{l}\text { Color from the general background of the official emblem of the } \\
\text { Zakarpattia Reformed Church }\end{array}$ \\
\hline $\begin{array}{l}\text { The unification of independent char- } \\
\text { ismatic Christian churches of Ukraine } \\
\text { (Full Gospel) }\end{array}$ & $\mathrm{CCC}$ & & $\begin{array}{l}\text { Color from the official emblem of the most common charismatic } \\
\text { currents in Ukraine - the Church of the Full Gospel and the Church } \\
\text { of the Renaissance }\end{array}$ \\
\hline $\begin{array}{l}\text { Other religious organizations of a char- } \\
\text { ismatic type }\end{array}$ & $\mathrm{OCCC}$ & & $\begin{array}{l}\text { Assigned from the free colors of the color scale as it approaches } \\
\text { the main denomination - the Twenty-first Century }\end{array}$ \\
\hline Jehovah witnesses & JW & & $\begin{array}{l}\text { One of the main teachings of this faith is the doctrine of children. } \\
\text { All the headings on official websites and printed publications are } \\
\text { marked with this color }\end{array}$ \\
\hline other Protestants & OP & & $\begin{array}{l}\text { Assigned from the free colors of the color scheme as it approaches } \\
\text { one of the prevailing religions - the Baptism of Eclecticism }\end{array}$ \\
\hline
\end{tabular}

\section{JEWISH SUBSPACE}

Association of Jewish Religious Organizations of Ukraine

JRO

Association of Chassidim Chabad Lubavich Jewish religious organizations of Ukraine

Other Jewish religious organizations
The color is close to the main color of the «Star of David» - the main symbol of Judaism

The color is close to the main color of the «Star of David» - the main symbol of Judaism (dark shade)

Assigned from free colors of colors as they approach one of the prevailing religions

\section{MUSLIM SUBSPACE}

Spiritual Administration of Muslims of Ukraine and other Muslim religious organizations
Light green is the sacred color of Islam, the color of the flag of the Prophet

\section{BUDDHIST SUBSPACE}

The Spiritual Administration of Buddhists of Ukraine and other Buddhist religious organizations
SAB

The sacred color of the followers of Lamaism, one of the directions of Buddhism. It symbolizes the sun and light. 


\section{ETHNO-CONFESSIONAL AND PAGAN SUBSPACES}

Ethno-confessional religious organizations

Organization of a pagan sense, including the Native Ukrainian National Faith (NUNF)

Religious organizations of the Society for Krishna Consciousness

Other ethno-confessional and pagan religious organizations

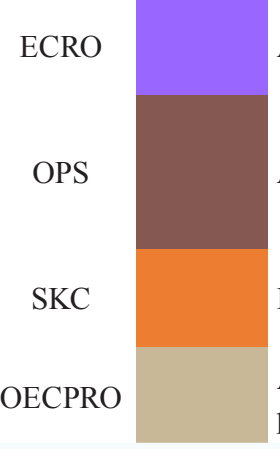

Assigned from free colors of color scheme

Assigned from free colors of color scheme

Holy color of Hare Krishna

Assigned from free colors of colors as they approach one of the prevailing religions

When displaying the religious space of individual settlements, it is possible to use a way of icons, similar to the cult buildings (Fig. 4). However, as experience shows, such maps are more difficult to read. However, when developing tourist maps, when applying sacred tourism objects, the use of the iconic method has the best effect for an ordinary tourist. This is explained by the fact that not all religious communities are displayed on such maps, but only the most significant religious buildings.

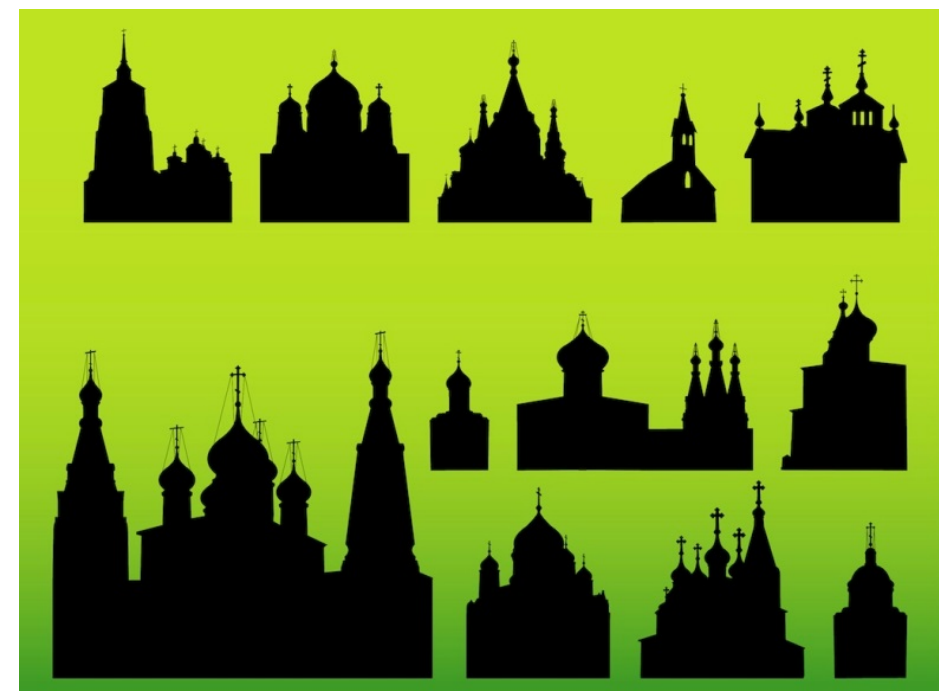

Fig. 4. Indicative icons for creating a map of sacred tourism potential (these vectors are taken from the Internet)

Through the use of the icon method, the map "Religious and Tourist Potential of the Chernivtsi Region" is drawn up (Fig. 5), which reflects the methodology of mapping with the purpose of creating tourist and tourist-scientific maps [12].

As it is possible to see, this map is quite understandable for the average reader, it carries a lot of information about the religious buildings, namely the material from which it is built, construction and confessional identity. Also, this map clearly reflects the administrative and territorial areas with the greatest religious and tourist potential, allowing more efficiently to compose tourist routes, choosing the main and secondary, for viewing tourists, objects.

Modern trends in the use of computer and geo-information technologies are very important in the compilation of cartographic maps of various levels and types, as well as in cartographic monitoring [3]. 


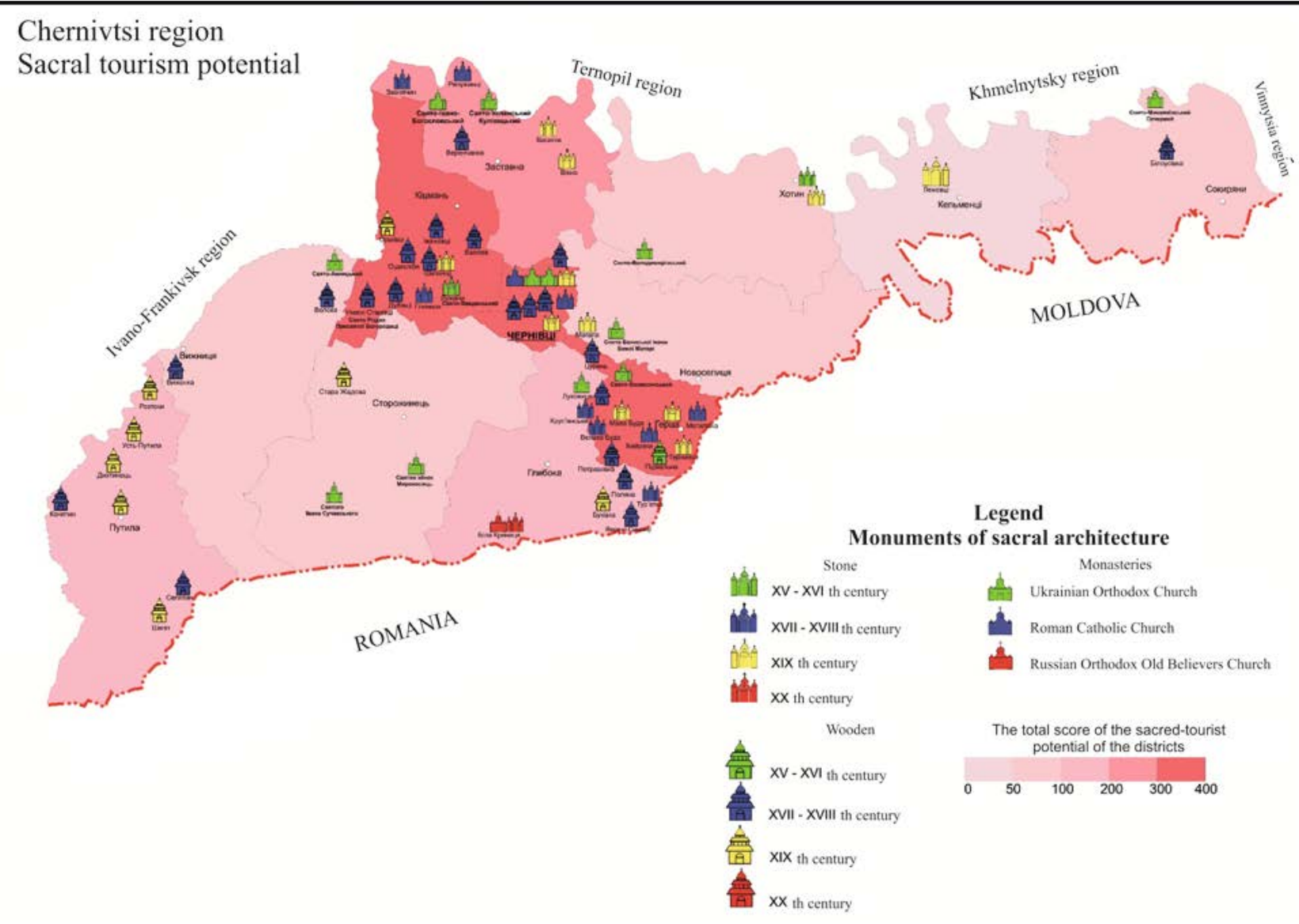

Fig. 5. "Religious and tourist potential of the Chernivtsi region" map

\section{Conclusions}

The creation of maps reflecting the confessional space of a particular region or the state as a whole today needs some methodological improvement. It is proposed to do this using a unified system of symbols and selection of mapping methods. Using established colors to display denominations will help better navigate and take in the displayed information. One should also take into account the abolition of the scale and informativeness of the maps of individual regions at the level of administrative-territorial regions or regions and at the level of settlements. When concluding the maps of confessional space, it is proposed to use the method of a circular cardiogram, where the size is to reproduce the total number of religious communities of all faiths, confessions and trends (or population), and by sectors, using the developed color scheme, to display its confessional structure.

By appointment, maps reflecting religious and confessional spaces can also be tourist. Especially important for the development of tourist routes is the map, reflecting the religious and tourist potential. At the conclusion of such maps, a method of icons should be used, where the size should reflect its historical and cultural significance (UNESCO's object, national or local meaning), and the background is confessional. The creation of such maps is of great importance for tour operators and tourists themselves, who can better choose areas for travel with the purpose of acquaintance with important religious objects.

\section{References}

[1] Andreeva, T. A., Rasskazova, E. V. (2002). Geoinformatsionnye tekhnologii v atlase «Russkoe Pravoslavie: istoriya, geografiya i kul'tura». GIS dlya ustoychivogo razvitiya territoriy. Saint Petersburg: ZAO «Karta», 129-132. 
[2] Ataman, L. V. (2015). Issledovanie sakral'nogo prostranstva regiona: metodologiya i printsipy. Pskovskiy regionologicheskiy zhurnal, 23, 107-117.

[3] Barladin, O. V., Dacenko, L. M., Parkhomenko, G. O. (2002). Suchasni ta perspektyvni napriamy zastosuvannia kompiuternykh tekhnolohii u kartohrafuvanni y vykorystanni kart. Lviv: LigaPres, 271-273.

[4] Gorokhov, S. A. (2012). Religioznaya identichnost' kak faktor formirovaniya konfessional'nykh regionov sovremennogo mira. Vestnik Moskovskogo universiteta. Seriya 5. Geografiya, 5, 49-55.

[5] Gukalova, I. V., Topchiev, A. G., Dimova, N. V., Shashero, A. N., Yavorskaya, V. V., Gladkiy, A. V. et. al. (2014). Sovremennoe obshhestvo i ego prostranstvennoe osmyslenie: geografiya chelovecheskogo razvitiya (Case Studies). Novosybyrsk: Izd. «SibAK», 130. walk, 416 .

[6] Tyler, H. S., Esposito, J. L. (2010). Geography of religion: where God lives, where pilgrims

[7] Klyuchko, L. V. (2008). Suspilno-heohrafichni doslidzhennia relihiinoi sfery. Chasopys sotsialnoekonomichnoi heohrafii, 5 (2), 216-220.

[8] Kogatko, Yu. L., Mezencev, K. V. (2009). Metody doslidzhennia heohrafii relihii: dotsilnist vykorystannia, systematyzatsiia, potentsial kartohrafichnoho ta tsentrohrafichnoho metodiv. Visnyk Kyiivskogo nacionalnogo universytetu imeni Tarasa Shevchenka. Geografiya, 56, 30-36.

[9] Kong, L. (1990). Geography and religion: trends and prospects. Progress in Human Geography, 14 (3), 355-371. doi: http://doi.org/10.1177/030913259001400302

[10] Kostaschuk, I., Kisil, R. (2016). Confessional Spase and its Structure in the Context of Human Geography. Chasopys sotsialno-ekonomichnoi heohrafii, 20 (1), 40-46.

[11] Kostashchuk, I. (2017). Konfesiinyi prostir Ternopilskoi oblasti: suspilno-heohrafichni aspekty. Naukovi zapysky Ternopilskoho natsionalnoho pedahohichnoho universytetu imeni Volodymyra Hnatiuka. Ser. Heohrafiia, 2 (43), 51-60.

[12] Kostashhuk, I. I. (2017). Metodyka balnoi otsinky relihiino-turystychnykh obiektiv. Heohrafiia ta turyzm, 41, 12-21.

[13] Kostashhuk, I. I. (2011). Terytorialna orhanizatsiia relihiinoi sfery rehioniv Ukrainy. Uchenye zapiski Krymskogo federal'nogo universiteta imeni V. I Vernadskogo. Geografiya. Geologiya, 24 (2-3), 137-143.

[14] Kovalchuk, A. S. (2003). Geografiya religii v Ukrayini. Lviv: Lviv. nacz. un-t im. I. Franka, 308 .

[15] Kuchabskyi, O. G. (2000). Integralne religiino-geografichne raionuvannya Lvivskoi oblasti. Naukovi zapysky ternopilskogo pedagogichnogo universytetu im. Volodymyra Gnatyuka. Seriya: geografiya, 1, 80-85.

[16] Liubitseva, O. O. (2009). Relihiina sytuatsiia v Ukraini ta yii rehionalni osoblyvosti. Ukrainskyi heohrafichnyi zhurnal, 4, 28-32.

[17] Keisuke, M. (2014). Geography of Religion in Japan: Religious Space, Landscape, and Behavior. New York: Springer, 199.

[18] Rudenko, L. G. (Ed.) (2007). Nacionalnyi atlas Ukrayiny. Kyiv: DNVP «Kartografiya», 440.

[19] Niemets, K. A., Niemets, L. M., Kliuchko, L. M. (2009). Prostorovi aspekty analizu relihiinoi sfery (na prykladi Kharkivskoi oblasti). Chasopys sotsialno-ekonomichnoi heohrafii, 6 (1), 151-157.

[20] Park, C. C. (1994). Sacred Worlds: an Introduction to. Geography and Religion. London: Routledge, 287.

[21] Patiichuk, V. O. (1998). Terytorialna orhanizatsiia relihiinoi sfery administratyvnoi oblasti (na prykladi Volynskoi oblasti). Lutsk: Volynskyi derzhavnyi universytet imeni Lesi Ukrayinky, 202.

[22] Pavlov, S. V., Mezencev, K. V., Lyubiceva, O. O. (1998). Geografiya religii. Kyiv: Artek, 504.

[23] Rovenchak, I. I. (1997). Geokulturni rysy konfesiino-geografichnogo podilu Zakhidnogo regionu Ukrayiny (na prykladi UGKCz). Ekonomiko-, socialno- i ekologo-geografichni problemy zakhidnoukrainskogo prykordonnya. Lviv: LDU, 69-78.

[24] Rudenko, L. G., Shevchenko, V. O. (1994). Karty dlya nezalezhnoi Ukrayiny. Visnyk geodeziyi ta kartografiyi, 1, 76-80. 
[25] Shevchenko, R. Iu. (2006). Heohrafo-topolohichne ta astronometrychne doslidzhennia kultovykh sporud Starodavnoho ta suchasnoho Kyieva. Kartohrafiia ta vyshcha shkola, 12, 113-126.

[26] Shevchenko, R. Iu. (2006). Osoblyvosti proektuvannia i vykorystannia kart tserkov ta monastyriv m. Kyieva riznykh epokh. Visnyk KNU im. Tarasa Shevchenka. Ser. Heohrafiia, 53, 50-53.

[27] Shevchenko, R. Iu. (2014). Prostorovi destynatsii sakralnoi arkhitektury m. Kyieva. Kyiv, 147.

[28] Shevchuk, L. T. (1999). Sakralna geografiya. Lviv: Svit, 160.

[29] Shukanov, P. V. (2012). Geograficheskie osobennosti globalizatsii i regionalizatsii mira. Region - 2012: strategiya optimal'nogo rozvitku. Kharkiv: KHNU imeni V. N. Karazina, 59-62.

[30] Khristov, T. T. (2005). Religioznyy turizm. Moscow: Izdatel'skiy tsentr «Akademiya», 288.

[31] Zastavnyi, F. D. (1994). Geografiya Ukrayiny. Lviv: Svit, 472.

[32] Zuckerman, P. (2003). Invitation to the Sociology of Religion. New York: Routledge, 166. 